\title{
Pharmacological and Toxicological Properties of Eugenol
}

\section{Öjenolün Farmakolojik ve Toksikolojik Özellikleri}

\author{
Solmaz MOHAMMADI NEJAD, Hilal ÖZGÜNEȘ, Nurşen BAŞARAN* \\ Hacettepe University, Faculty of Pharmacy, Department of Pharmaceutical Toxicology, Ankara, Turkey
}

\begin{abstract}
Eugenol is a volatile phenolic constituent of clove essential oil obtained from Eugenia caryophyllata buds and leaves. It is a functional ingredient of numerous products which have been used in the pharmaceutical, food and cosmetic industry in restricted concentrations. Its derivatives have been used in medicine as a local antiseptic and anesthetic. The wide range of eugenol activities includes antimicrobial, anti-inflammatory, analgesic and antioxidant. Although eugenol is considered safe as a product, due to the vast range of different applications and extensive use, there has been a great concern about its toxicity in recent years. However, studies about cytotoxicity and genotoxicity of eugenol are very limited and controversial. The pharmacological and toxicological properties of eugenol will be discussed in this review.
\end{abstract}

Key words: Eugenol, clove oil, pharmacological activity, toxicity, cytotoxicity, genotoxicity

Öz

Öjenol, Eugenia caryophyllata'nın yaprak ve tomurcuklarından elde edilen, karanfil yağının fenolik yapıdaki uçucu bir bileșiğidir. İlaç, gıda ve kozmetik endüstrisinde sınırlı miktarlarda kullanılan, çok sayıda ürünün işlevsel bir bileşenidir. Türevlerinin lokal antiseptik ve anestezik olarak tıpta kullanımı bulunmaktadır. Geniş aralıktaki farmakolojik etkileri arasında antimikrobiyal, antiinflamatuvar, analjezik, antioksidan ve antikanser etkiler yer almaktadır. Öjenol genel olarak güvenli bir bileşik olarak değerlendirilir ancak çok farklı uygulamaları ve yaygın kullanım alanları nedeniyle, toksisitesi son yıllarda ilgi odağı olmuştur. Öjenolün sitotoksisitesi ve genotoksisitesi konusundaki çalışmalar da yetersiz ve çelişkilidir. Bu derlemede öjenolün farmakolojik ve toksikolojik özellikleri tartışılacaktır.

Anahtar kelimeler: Öjenol, karanfil yağı, farmakolojik aktivite, toksisite, sitotoksisite, genotoksisite

\section{INTRODUCTION}

Eugenol $\left(\mathrm{C}_{10} \mathrm{H}_{12} \mathrm{O}_{2}\right.$ or $\left.\mathrm{CH}_{3} \mathrm{C}_{6} \mathrm{H}_{3}\right)$ is a volatile phenolic constituent of clove essential oil obtained from Eugenia caryophyllata buds and leaves, mainly harvested in Indonesia, India and Madagascar. The name supposedly is derived from the scientific name for clove E. caryophyllata tree which has large leaves and flower buds which turn to red color when they are ready for collection.,2 Eugenol is the main extracted constituent $(70-90 \%)$ of cloves and is responsible for clove aroma.'

Eugenol, a phenylpropanoid, is pale yellow oil with a spicy aroma with the molecular weight of $164.2 \mathrm{~g} / \mathrm{mol}$. This molecule is a weak acid which is soluble in organic solvents and specially extracted from clove oil, nutmeg, cinnamon, basil and bay leaf.

There are different types of essential oil extracted from parts of clove. The oil derived from the flower buds of clove mainly consists of eugenol (60-90\%), eugenyl acetate, caryophyllene and other substances, whereas oil derived from the leaves of the clove tree consists of eugenol (82-88\%) and very little eugenyl acetate, and other minor constituents. The oil derived from the twigs of cloves consists of $90-95 \%$ of eugenol. Eugenol also can be produced synthetically by the allylation of guaiacol with allylchlorid. ${ }^{3,4}$

Since ancient times, clove oil has been used as an antimicrobial, antiseptic and antispasmodic in Chinese traditional medicine. Nowadays, there is also a wide range of use of eugenol for several purposes such as household products, fragrance in soaps and cosmetics, skin care products, flavoring substance for food, dental and pharmaceutical products.'

Eugenol causes an enhancement in skin penetration of diverse drugs. It is also used in agricultural applications to protect foods from microorganisms such as Listeria monocytogenes and Lactobacillus during storage, as a pesticide and fumigant. ${ }^{5}$ Eugenol is useful for treatment of skin infections, skin lesions and inflammatory disorders. However, some reports show 


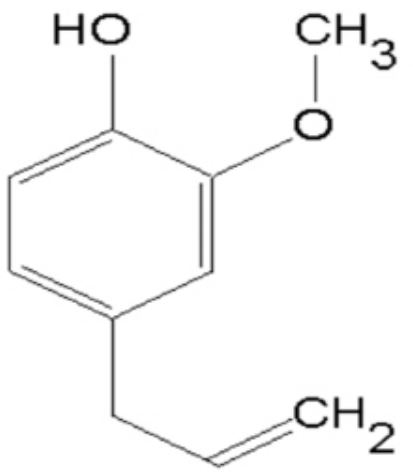

Figure 1. Chemical structure of eugenol $\left(\mathrm{C}_{10} \mathrm{H}_{12} \mathrm{O}_{2}\right)$

that higher concentrations of undiluted clove oil may result in some symptoms. Indeed, an excessive dose of eugenol was considered as toxic. ${ }^{2,5}$

The US Food and Drug Administration approved the use of clove oil as a flavoring substance in the food industry, as a fragrance in cosmetics industry and in dentistry as a natural analgesic and antiseptic. ${ }^{6}$

There are relatively few human studies about the pharmacokinetic and effects of eugenol. Animal studies have suggested that after inhalation of the smoke of clove cigarettes, minor amounts of eugenol may be absorbed from the lung. Also some in vitro studies indicated that eugenol undergoes biotransformation in hepatocytes. ${ }^{7}$ An investigation of male and female healthy volunteers demonstrated that eugenol was absorbed and metabolized after oral administration rapidly. It was almost completely excreted in the urine within 24 hours and the urine contained conjugates of eugenol. Results revealed that only less than $1 \%$ of administrated dose was excreted as non-metabolized in urine. Analysis of urine also demonstrated that more than $90 \%$ of metabolic products are phenolic conjugates and $50 \%$ of the conjugated metabolites were eugenol-glucuronide and eugenol-sulfate. Other observed metabolic routes were the epoxide-diol pathway, synthesis of a thiophenol and of a substituted propionic acid, allylic oxidation, and migration of the double bond. ${ }^{8}$

In an in vitro study, all assessed metabolites have been found to have an aromatic hydroxyl group. The reaction of the hydroxyl group with glucoronate or sulfate causes the formation of conjugates which are finally excreted in the urine. Similarities have been observed between the metabolism of eugenol in human and rodents. ${ }^{9}$

Guenette et al. ${ }^{10}$ suggested that in rats, the half-life $\left(t_{1 / 2}\right)$ of eugenol in plasma is about 14 hours and in blood is 18 hours.

\section{Pharmacological activities of eugenol}

Based on available experimental data, many phenolic compounds such as eugenol show antioxidant capacity and free radical scavenging activity. ${ }^{5}$ The antioxidant activity of eugenol and one of its isomers isoeugenol has been studied by using iron-mediated lipid peroxidation and auto-oxidation of $\mathrm{Fe}^{2+}$. Eugenol had the inhibitory effect on lipid peroxidation, with an $\mathrm{IC}_{50}$ value of about $80 \mu \mathrm{M}$, which was eightfold the value of isoeugenol however; this effect was less potent than the effect of isoeugenol. The functional mechanism of both compounds was evaluated and the obtained results indicated that the antioxidant activity of eugenol is potent to form complexes with reduced metals. Isoeugenol causes a decrease in the formation of iron-oxygen chelate complex, which is the initiating factor of lipid peroxidation." In an experiment by using the hydroxyl radical scavenging tests, eugenol exhibited antioxidant capacity in a dose dependent manner..$^{12}$ Ogata et al. ${ }^{13}$ suggested that the inhibitory mechanism of eugenol in lipid peroxidation has two steps. In fact, eugenol interferes with the chain reactions by trapping the active oxygen. Also eugenol is metabolized to dimer which inhibits lipid peroxidation.

In male rats, eugenol showed anesthetic effects and reports demonstrated a dose dependent anesthesia after administration of about $50-60 \mathrm{mg} / \mathrm{kg}$ i.v. ${ }^{14}$

\section{Antibacterial activities of eugenol}

The effects of eugenol on the growth of some species of Gram-positive (Bacillus cereus; Bacillus subtilis; Staphylococcus aureus) and Gram-negative (Escherichia coli; Salmonella typhi; Pseudomonas aeruginosa) bacteria were assessed by using the agar well diffusion method. Eugenol has shown an inhibitory effect on the growth of the $P$. aeruginosa at the concentration of $1000 \mu \mathrm{g} / \mathrm{mL}$. The complete inhibitory effect against such bacteria is shown at $2000 \mu \mathrm{g} / \mathrm{mL}$. In this study, ampicillin (1 mg/ $\mathrm{mL}$ ) is used as positive control and similar effects of eugenol also have confirmed against various pathogens such as $E$. coli, $B$. cereus, Helicobacter pylori, S. aureus, Staphylococcus epidermidis, Streptococcus pneumoniae and Streptococcus pyogenes. 15,16

The combination of eugenol with a conventional antibiotic has been evaluated to detect the synergistic effect against Gramnegative bacteria. In the eugenol treated cells, $50 \%$ loss of membrane integrity was demonstrated which enhanced the activity of studied antibiotics. The combination of eugenol with two antibiotics, vancomycin and a $\beta$-lactam, showed an increased membrane damage in bacteria which means a synergistic effect. It has been also demonstrated that penetration of vancomycin and $\beta$-lactam, in combination with eugenol, has increased and resulted in more antimicrobial effect. ${ }^{17}$

In another experimental study, the antibacterial effect of several natural products; eugenol, cinnamaldehyde, thymol, carvacrol and a combination of all mentioned agents have been studied against the E. coli. The broth micro-dilution assay has been used for the evaluation. Results demonstrated that among mentioned substance, eugenol has the lowest antibacterial effect however, the combination of eugenol and cinnamaldehyde, thymol and carvacrol, showed a synergistic antibacterial activity. ${ }^{18}$

The mechanism action of eugenol on the bacterial membrane of $L$. monocytogenes, S. pyogenes, Proteus vulgaris and E. coli has been examined. Results displayed that eugenol induces cell lysis through the leakage of protein and lipid in the cell 
membrane. Furthermore, it seems that the time of exposure of cells to eugenol is important. Because both the cell wall and membrane of the treated Gram-negative and Gram-positive bacteria were considerably damaged after about $120 \mathrm{~min}$ of exposure. ${ }^{19}$

Eugenol at the concentrations of 16 to $128 \mu \mathrm{g} / \mathrm{mL}$, decreased the hemolytic activity and the release of tumor necrosis factor alfa $(T N F-\alpha)$ in a dose dependent manner. It is also found that depending on the concentration of eugenol, production of staphylococcal enterotoxin has been reduced significantly. As a result, it is suggested that eugenol could be used as a food additive because of the inhibitory effect on growth of bacteria and suppressive effect on the production of exotoxins of $S$. aureus. $^{20}$

\section{Anti-inflammatory effects of eugenol}

Investigations of anti-inflammatory effects of eugenol, have suggested that this compound is able to suppress the expressions of cyclooxygenase II enzyme. Eugenol dimers can inhibit the expression of cytokines in macrophages, which are stimulated by polysaccharides. Eugenol also has an inhibitory effect on cell proliferation via suppression of NF-Kappa B $(N F-\kappa B)$. Eugenol suppresses the activation of $N F-\kappa B$ which induces reduction in the incidence of gastric tumors. Eugenol can also modulate the expression of NF- $\mathrm{KB}$ target genes which are responsible for the regulation of cell proliferation and cell survival. Because of these suggested activities, eugenol has been indicated to have chemo preventive effect. ${ }^{21}$

Macroscopic studies, clinical evidences of collagen-induced arthritis and treatment with eugenol in a murine model, showed that eugenol may have inhibitory effects on mononuclear cell infiltration into the knee joints of arthritic mice. Eugenol lowered the levels of cytokines such as TNF- $\alpha$, interferon gamma and TNF- $\beta$ in the ankle joints. The in vitro cell viability was assessed by MTT method and achieved results exhibited that cells were not affected by eugenol treatment. It is suggested that eugenol may have recovery effects on arthritis and can be useful as a beneficial supplement in the treatment of arthritis. ${ }^{22}$

Eugenol has been found to exert antipyretic activity in rabbits when given intravenously and intragastrically and may reduce fever through a similar central action to allopathic antipyretic drugs such as acetaminophen. ${ }^{23}$

Eugenol at the concentrations of $0.2-20 \mu \mathrm{m}$, is suggested to be able to produce a dose dependent and reversible vasodilator response that are partially dependent on the endothelium. ${ }^{24}$ It has also been found to have a preventive effect on dopamine depression and lipid peroxidation, which can protect depression induced by 6-hydroxyl dopamine. Eugenol has prevented depression by decreasing the lipid peroxidation and stimulating reduced glutathione (GSH). ${ }^{25}$

\section{Toxicity of eugenol}

Eugenol is considered safe as a food additive, but due to the wide range of different applications and also the extensive use and availability of clove oil; there is a great concern about its toxicity in recent years.
Results of a case study indicated that ingestion of $5-10 \mathrm{~mL}$ of clove oil by a two-year boy resulted in distressing and crying and $3 \mathrm{~h}$ after ingestion, conditions were deteriorated. The acidosis marked and the patient was in deep coma. During $8 \mathrm{~h}$, he suffered from a generalized seizure, and within $24 \mathrm{~h}$, failure in liver function and also disseminated intravascular coagulopathy was noted. Within one week after ingestion and after severe symptomatic treatment, the patient gained consciousness and recovered. In terms of hepatotoxic effects, results showed some similarities between eugenol and paracetamol poisoning. ${ }^{26}$

Intravenous infusion of eugenol at $4 \mu \mathrm{L}$ and $8 \mu \mathrm{L}$ caused acute respiratory distress with hemorrhagic pulmonary edema in rats and it is suggested that at least a part of damage is related to oxidative stress. ${ }^{27}$ In an in vitro experiment on isolated rat hepatocytes, after $5 \mathrm{~h}$ exposure to eugenol, hepatotoxicity and cell damage in more than $85 \%$ of cells were demonstrated. Administration of acetyl cysteine had preventive effects on cell death in the same cell line. ${ }^{28}$

Since cinnamon and clove have lipophilic properties, they are able to penetrate the cell membrane and then become accessible to intracellular organelles such as mitochondria. Recent studies indicated some inhibitory effects of such spices on the activity of $\mathrm{Na}^{+} / \mathrm{K}^{+}$ATPase in kidney and intestine. It is also possible that spices have toxic effects on mitochondrial function which leads to decrease in ATP level. Reductions of ATP level can influence the mechanism of cell growth, viability and aging. ${ }^{29}$

Studies on the toxic effects of anesthetic doses of eugenol on African clawed frogs demonstrated damage in kidney and some morphological alteration and cell apoptosis in renal cells. ${ }^{30}$

The oral intake of eugenol in different doses during a 15 day period may cause some changes in blood chemistry. Moreover it causes an increase in aspartate aminotransferase, alanine aminotransferase, and total bilirubin levels, but it seems that such effects are not dose dependent. ${ }^{31}$

\section{Cytotoxicity of eugenol}

The cytotoxic effects of eugenol, induction of reactive oxygen species (ROS) production and reduced levels of GSH have been studied in human submandibular cell line. It is suggested that formation of benzyl radicals is the main cause of low GSH of eugenol is found to be related to ROS-independent mechanisms. Eugenol has been found to exert less cytotoxic effects compared to isoeugenol and such effects are dose dependent. ${ }^{32}$

Eugenol is also found potential to decrease the activity of dehydrogenase enzymes in human osteoblastic cells in a dose dependent manner. ${ }^{33}$

The cytotoxic effects of some of root canal sealer agents based on zinc-oxide eugenol (endofill) and sealer 26 were also studied. Results showed that both agents have cytotoxic effects, but the toxicity of "sealer 26" on macrophages is more than endofill. ${ }^{34}$ Anpo et al. ${ }^{35}$ evaluated the cytotoxic effects of eugenol on human pulp cells and also the expression of molecular markers in osteogenic differentiation. Observations suggested that eugenol used for endodontic treatment, may have cytotoxic effects on the normal function of stem cells. 
Another study evaluated the apoptosis induced by eugenol in human breast cancer cells. Release of the lactate dehydrogenase enzyme, percentage of cell viability and cytotoxicity, morphological changes and quantitation of DNA fragments have been studied. The findings demonstrated that the increase of cell apoptosis and DNA fragmentation are dose dependent. ${ }^{36}$

The cytotoxicity of eugenol was studied in three different malignant and nonmalignant human derived cells. The malignant Hep G2 hepatoma cells, malignant Caco-2 colon cells and nonmalignant human $\mathrm{VH} 10$ fibroblasts were chosen to determine the cytotoxicity of eugenol. Eugenol was found to be toxic in human VH10 fibroblasts and Caco-2 colon cells but not in Hep G2 hepatoma cells. Eugenol at concentrations under 600 $\mu \mathrm{M}$ significantly caused an increase in DNA breaks in human $\mathrm{VH} 10$ fibroblast cells. But the degree of such damage in Caco-2 colon cells was found to be lower. The DNA damaging effect was not observed in Hep G2 cells. ${ }^{37}$

The effects of eugenol and a chemotherapeutic drug gemcitabine were investigated in colon cancer cells. The combination of eugenol and gemcitabine resulted in a decrease in cell viability of $84 \%$ (eugenol alone) to $47 \%$ (combination of eugenol-gemcitabine). Results showed that eugenol alone causes $84 \%$ decrease and gemcitabine causes $51 \%$ decrease in cell viability. The colon cancer cells were treated with eugenol resulted in increased lipid layer breaking. Furthermore, eugenol has been found to induce apoptosis by destruction the mitochondrial membrane potential and production of reactive oxygen species. ${ }^{38}$

Eugenol showed different degrees of cytotoxicity in $\mathrm{HL}$ 60 cancer cells and inhibited the cell growth by $50 \%$ at a concentration of $23.7 \mu \mathrm{M}$. Results demonstrated a significant increase of fragmented DNA caused by eugenol. Also eugenol has the potential to induce the induce ROS-dependent apoptosis in $\mathrm{HL}-60$ cell line. ${ }^{39}$

It was found that eugenol is able to inhibit the proliferation of melanoma cells. Such effect resulted in a considerable delay in tumor growth and about $40 \%$ decrease in the size of tumor. Moreover, approximately $50 \%$ of the animals in the control group died because of metastatic growth, while no sign of metastasis was observed in the treatment group. Results of the experiments on the anti-proliferative mechanism of eugenol in the malignant melanoma cell line (WM1205L) in humans detected that eugenol arrests cells in the $S$ phase of the cell cycle and induces apoptosis by this function. ${ }^{40}$

\section{Genotoxicity of eugenol}

Authors have suggested that a moderate to severe toxic effects of zinc oxide eugenol in V79 cell line and also demonstrated that these effects are dose dependent, suggesting that eugenol has genotoxic effects. ${ }^{41}$ On the other hand, the chemopreventive effect of eugenol on DNA damage induced by 7,12 dimethylbenzanthracene (DMBA) has been evaluated in MCF-7 cells. The observations suggested that eugenol was potent to protect DNA against genotoxic damage induced by
DMBA. Eugenol is able to suppress the DMBA activation and acts as a potential chemopreventive compound. ${ }^{42}$

After oral administration of eugenol $(0.4 \%$ in the diet) for two weeks in rodents, the frequency of micronucleated erythrocytes was decreased significantly. The results provided that eugenol has the capacity of mutagenicity in male mouse and causes mutation, particularly in the anaphase of polychromatic erythrocytes of male mouse. ${ }^{43}$

The genotoxic capacity of various phenolic compounds such as eugenol, isoeugenol and safrole has been evaluated by using the wing spot test of Drosophila melanogaster (common fruitfly). The results of this experiment demonstrated that at the same concentrations, isoeugenol clearly was not genotoxic. Observations also showed that eugenol and safrole are able to produce a positive recombinogenic response which is related to a high CYP P450 activation capacity. The genotoxicity of eugenol is related to reactive metabolites and recombinogenic compounds of it. 44

The evaluation of antigenotoxicity effects of eugenol in mice with micronucleus test, suggests that the antigenotoxic effects of eugenol may be dose related..$^{45}$ In another experimental study, the effect of eugenol on tobacco-induced genotoxicity was evaluated by the Ames Salmonella/microsome test. The obtained data displayed that eugenol at concentrations of 0.5-1 mg/plate, has an inhibitory effect on tobacco-induced mutagenicity. But 150 mg/day of eugenol was ingested by ten non-smoking healthy male adults and findings suggested that eugenol has no antigenotoxic activity on human. ${ }^{46}$

\section{Immunotoxicity of eugenol}

Findings about the potency of eugenol and clove oil in inducing allergy and hypersensitivity are controversial. Several adverse effects have been observed after use of dental products which contain eugenol. Localized irritation of the skin; ulcers, allergic dermatitis, tissue necrosis and rarely even anaphylactic-like shock have been reported in different studies. ${ }^{47}$

The allergic capacity of eugenol containing fragrance was evaluated in approximately 24.000 individuals. Findings reported that $25.5 \%$ of health care workers, $16.5 \%$ of non-health care workers, $39.39 \%$ of metal workers and $16.3 \%$ of people in other occupations showed allergic reactions to eugenol. ${ }^{48}$

An 8 year old boy reported a type 1 immediate hypersensitive reaction to the eugenol after root canal was medicated with sodium hypochlorite and sealed with zinc oxide eugenol. About 1 min after the zinc oxide eugenol placement, the patient was anxious and excited, with evident erythema on the parts of the face, neck, torso, upper and lower limbs, itchiness and redness extending behind the ear. Cutaneous examination revealed extensive weal of various sizes and shapes with no angioedema or mucosal involvement. Owing to the fact that the erythema was noticed after the placement of zinc oxide eugenol, skin prick test for zinc oxide eugenol was performed and showed positive response for eugenol (10\%) and negative responses for zinc oxide (10\%), formaldehyde (1\% aq) and sodium hypochlorite. Intravenous injection of $100 \mathrm{mg}$ of 
hydrocortisone hemi succinate was administrated immediately and zinc oxide eugenol temporary dressing was replaced with non-eugenol containing material. Forty-five minutes later, the patient presented reduced erythema on the face, neck and hands however; some studies also showed that eugenol alone or clove oil has a very low activity to induce these allergic effects. ${ }^{49,50}$

\section{CONCLUSION}

Eugenol has been recognized as a safe food additive in the generally recognized as safe substance classification under the sections of Federal Food, Drug and Cosmetics Administration. However, extensive toxicity studies should be performed to confirm that eugenol is safe for general public health. Research on the characteristics of clove oil and eugenol is still ongoing. Structurally eugenol is a simple molecule, but it is used extensively for varied purposes in various industries such as pharmaceutical, food and cosmetics, dentistry, agriculture and others.

Furthermore, some small changes in the molecular structure of eugenol, may lead in different molecular properties which can have different biological activities. Observations from several studies show synergistic effects of eugenol and other antimicrobial compounds which allow use of eugenol as a proper food additive. According to antimicrobial experiments, eugenol also is potent to damage the membranes of bacteria which may results in the increase of the penetration of some antibiotics.

Although there are extensive researches on plant toxicity, studies related to the toxic effects of eugenol and clove oil, are still very limited. Especially chronic toxicity, cytotoxicity and genotoxicity studies are lacking.

In conclusion, different properties and activities of eugenol are still undiscovered very well and should be further explored by more in vitro and in vivo long-term human research.

Conflict of Interest: No conflict of interest was declared by the authors.

\section{REFERENCES}

1. Barceloux DG. Medical Toxicology of Natural Substances: Foods, Fungi, Medicinal Herbs, Plants and Venomous Animals, Wiley: Hoboken; New Jersey; 2008.

2. Basch E, Gasparyan A, Giese N, Hashmi S, Miranda M, Sollars D, Seamon E, Tanguay-Colucci S, Ulbricht C, Varghese M, Vora M, Weissner W. Clove (Eugenia aromatica) and clove oil (eugenol). Natural standard monograph (www.naturalstandard.com) copyright ${ }^{\odot}$ 2008. J Diet Suppl. 2008;5:117146.

3. Barnes J, Anderson L, Phillipson D. Herbal Medicine. Pharmaceutical Press; London; 2007.

4. Oyedemi So, Okoh Al, Mabinya LV, Pirochenva G, Afolayan AJ. The Proposed mechanism of bactericidal action of eugenol, $\alpha$-terpineol and terpinene against Listeria monocytogenes, Streptococcus pyogenes, Proteus vulgaris and Escherichia coli. Afr J Biotechnol. 2009;8:1280-1286.
5. Kamatou GP, Vermaak I, Viljoen AM. Eugenol; from the remote Maluku Islands to the international market place: a review of a remarkable and versatile molecule. Molecules. 2012;17:6953-6981.

6. Chapter 6-Clove Oil (Eugenol), https://www.marinwater.org/Document Center/View/253, Acccessed: 20 September 2016.

7. Thompson DC, Constantin-Teodosiu D, Moldéus P. Metabolism and cytotoxicity of eugenol in isolated rat hepatocytes. Chem Biol Interact. 1991;77:137-147.

8. Fisher IU, von Unruh GE, Dangler HJ. The metabolism of eugenol in man. Xenobiotica. 1990;20:209-222.

9. Eugenol and Related Hydroxyallylbenzene Derivatives, http://www. inchem.org/documents/jecfa/jecmono/v56je09.pdf, Accessed: 10 August 2016.

10. Guenette SA, Ross A, Beaudry F, Vachon P. Pharmacokinetics of eugenol and its effects on thermal hypersensitivity in rats. Eur $\mathrm{J}$ Pharmacol. 2007;562:60-67.

11. Ito M, Murakami K, Yoshino M. Antioxidant action of eugenol compounds: role of metal ion in the inhibition of lipid peroxidation. Food Chem Toxicol. 2005:43:461-466.

12. Singh G, Maurya S, DeLampasona MP, Catalan CA. A comparison of chemical, anti-oxidant and antimicrobial studies of cinnamon leaf and bark volatile oils, oleoresins and their constituents. Food Chem Toxicol. 2007; 45:1650-1661.

13. Ogata M, Hoshi M, Urano S, Endo T. Antioxidant activity of eugenol and related monomeric and dimeric compounds. Chem Pharm Bull (Tokyo). 2000;48:1467-1469.

14. Guenette SA, Beaudry F, Marier JF, Vachon P. Pharmacokinetics and anesthetic activity of eugenol in male sprague-dawley rats. $J$ Vet Pharmacol Ther. 2006;29:265-270.

15. Leite AM, Lima EO, Souza EL, Diniz MFFM, Trajano VN, Medeiros IA. Inhibitory effect of $\beta$-pinene, $\alpha$-pinene and eugenol on the growth of potential infectious endocarditis causing gram-positive bacteria. Braz $\mathrm{J}$ Pharmacol Sci. 2007:43:121-126.

16. Ali SM, Khan AA, Ahmed I, Musaddiq M, Ahmed KS, Polasa H, Rao LV Habibullah, CM, Sechi LA, Ahmed N. Antimicrobial activities of eugenol and cinnamaldehyde against the human gastric pathogen Helicobacter pylori. Ann Clin Microbiol Antimicrob. 2005;4:20.

17. Hemaiswarya S, Doble M. Synergistic interaction of eugenol with antibiotics against Gram-negative bacteria. Phytomedicine. 2009;16:9971005.

18. Pei RS, Zhou F, Ji BP, Xu J. Evaluation of combined antibacterial effects of eugenol, cinnamaldehyde, thymol, and carvacrol against $E$. coli with an improved method. J Food Sci. 2009;74:379-383.

19. Oyedemi SO, Okoh Al, Mabinya LV, Pirochenva G, Afolayan AJ. The proposed mechanism of bactericidal action of eugenol $\alpha$-terpineol and terpinene against Listeria monocytogenes, Streptococcus pyogenes, Proteus vulgaris and Escherichia coli. Afr J Biotechnol. 2009;8:1280-1286.

20. Qiu J, Feng H, Lu J, Xiang H, Wang D, Dong J, Wang J, Wang X, Liu J, Deng $X$. Eugenol reduces the expression of virulence-related exoproteins in staphylococcus aureus. Appl Environ Microbiol 2010;76:5846-5851.

21. Leem HH, Kim EO, Seo MJ, Choi SW. Antioxidant and anti-inflammatory activities of eugenol and its derivatives from clove (Eugenia caryophyllata Thunb.) Korean J Food Sci. 2011;40:1361-1370.

22. Grespan R, Paludo M, Lemos Hde P, Barbosa CP, Bersani-Amado CA, Dalalio MM, Cuman RK. Anti-arthritic effect of eugenol on collageninduced arthritis experimental model. Bio Pharm Bull. 2012;35:18181820. 
23. Feng J, Lipton JM. Eugenol: antipyretic activity in rabbits. Neuropharmacology. 1987;26:1775-1778.

24. Criddle DN, Madeira SV, Soares de Moura R. Endothelium-dependent and independent vasodilator effects of eugenol in the rat mesenteric vascular bed. J Pharma Pharmacol. 2003;55:359-365.

25. Kabuto $H$, Yamanushi TT. Effects of zingerone [4-(4-hydroxy-3methoxyphenyl)-2-butanone] and eugenol [2-methoxy-4-(2-propenyl) phenol] on the pathological progress in the 6-hydroxydopamine-induced Parkinson's disease mouse model. Neurochem Res. 2011;36:2244-2249.

26. Hartnoll G, Moore D, Douek D. Near fatal ingestion of oil of cloves. Arch Dis Child. 1993;69:392-393.

27. Wright SE, Baron DA, Heffner JE. Intravenous eugenol causes hemorrhagic lung edema in rats: proposed oxidant mechanisms. J Lab Clin Med. 1995;125:257-264.

28. Soundran V, Namagiri T, Manonayaki S, Vanithakumari G. Hepatotoxicity of eugenol. Anc Sci Life. 1994;13:213-217.

29. Usta J, Kreydiyyeh S, Bajakian K, Nakkash-Chmaisse H. In vitro effect of eugenol and cinnamaldehyde on membrane potential and respiratory chain complexes in isolated rat liver mitochondria. Food Chem Toxicol. 2002;40:935-940.

30. Goulet F, Vachon P, Helie P. Evaluation of the toxicity of eugenol at anesthetic doses in African clawed frogs (Xenopus laevis). Toxicol Pathol. 2011;39:471-477.

31. Li J, Yu Y, Yang Y, Liu X, Zhang J, Li B, Zhou X, Niu J, Wei X, Liu Z. A 15day oral dose toxicity study of aspirin eugenol ester in Wistar rats. Food Chem Toxicol. 1980;50:1980-1985.

32. Atsumi T, Fujitsawa S, Tonosaki K. A comparative study of the antioxidant/prooxidant activities of eugenol and isoeugenol with various concentrations and oxidation conditions. Toxicol In Vitro. 2005;19:10251033.

33. Ho YC, Haung FM, Chang YC. Mechanisms of cytotoxicity of eugenol in human osteoblastic cells in vitro. Int Endod J. 2006;39:389-393.

34. Queiroz CE, Soares JA, Leonardo Rde T, Carlos IZ, Dinelli W. Evaluation of cytotoxicity of two endodontic cements in a macrophage culture. $J$ Appl Oral Sci. 2005;13:237-242

35. Anpo M, Shirayama K, Tsutsui T. Cytotoxic effect of eugenol on the expression of molecular markers related to the osteogenic differentiation of human dental pulp cells. Odontology. 2011;99:188-192.

36. Vidhya N, Devaraj SN. Induction of apoptosis by eugenol in human breast cancer cells. Indian J Exp Biol. 2011;49:871-878.
37. Slameňová, D, Horváthová, E, Wsólová, L, Šramková, M, Navarová J. Investigation of anti-oxidative, cytotoxic, DNA-damaging and DNAprotective effects of plant volatiles eugenol and borneol in humanderived HepG2, Caco-2 and VH10 cell lines. Mutat Res. 2009;677:46-52.

38. Jaganathan SK, Mazumdar A, Mondhe D, Mandal M. Apoptotic effect of eugenol in human colon cancer cell lines. Cell Biol Int. 2011;35:607-615.

39. Yoo CB, Han KT, Cho KS, Ha J, Park HJ, Nam JH, Kil UH, Lee KT. Eugenol isolated from the essential oil of Eugenia caryophyllata induces a reactive oxygen species-mediated apoptosis in $\mathrm{HL}-60$ human promyelocytic leukemia cells. Cancer Lett. 2005;225:41-52.

40. Ghosh R, Nadiminty N, Fitzpatrick JE, Alworth WL, Slaga TJ, Kumar AP. Eugenol causes melanoma growth suppression through inhibition of E2F1 transcriptional activity. J Biol Chem. 2005;280:5812-5819.

41. Huang $T H$, Lee $H$, Kao $C T$. Evaluation of the genotoxicity of zinc oxide eugenol-based, calcium hydroxide-based, and epoxy resin-based root canal sealers by comet assay. J Endod. 2001;27:744-748.

42. Han EH, Hwang YP, Jeong TC, Lee SS, Shin JG, Jeong HG. Eugenol inhibit 7,12-dimethylbenz[a]anthracene-induced genotoxicity in MCF-7 cells: Bifunctional effects on CYP1 and NAD(P)H:quinone oxidoreductase. FEBS Lett. 2007:581:749-756.

43. Rompelberg CJ, Stenhuis WH, Vogel N, Osenbruggen WA, Schouten A, Verhagen $\mathrm{H}$. Antimutagenicity of eugenol in the rodent bone marrow micronucleus test. Mutat Res. 1995;346:69-75.

44. Munerato MC, Sinigaglia M, Reguly ML, de Andrade HH. Genotoxic Effects of Eugenol, Isoeugenol and Safrole in the Wing Spot Test of Drosophila Melanogaster. Mutat Res. 2005;582:87-94.

45. Woolverton CJ, Fotos PG, Mokas MJ, Mermigas ME. Evaluation of eugenol for mutagenicity by the mouse micronucleus test. J Oral Pathol. $1986 ; 15: 450-453$

46. Sukumaran K, Kuttan R. Inhibition of tobacco-induced mutagenesis by eugenol and plant extracts. Mutat Res. 1995;343:25-30.

47. Sarrami N, Pemberton MN, Thornhill MH. Adverse reactions associated with the use of eugenol in dentistry. Brit Dent J. 2002;193:257-259.

48. Buckley DA, Rycroft RJ, White IR, McFadden JP. Fragrance as an occupational allergen. Occup Med (Lond). 2002;52:13-16.

49. Tammannavar P, Pushpalatha C, Jain S, Sowmya SV. An unexpected positive hypersensitive reaction to eugenol. BMJ Case Rep. 2013:2013.

50. Rothenstein AS, Booman KA, Dorsky J, Kohrman KA, Schwoeppe EA Sedlak RI, Steltenkamp RJ, Thompson GR. Eugenol and clove leaf oil: a survey of consumer patch-test sensitization. Food Chem Toxicol. 1983;21:727-733. 